\title{
PENGEMBANGAN KERAJINAN SANGKAR BURUNG KELURAHAN KADIPIRO, SURAKARTA, JAWA TENGAH.
}

\author{
Aan Sudarwanto \\ Jurusan Kriya \\ Fakultas Seni Rupa dan Desain ISI Surakarta \\ Rahayu Adi Prabowo \\ Jurusan Kriya \\ Fakultas Seni Rupa dan Desain ISI Surakarta \\ Ari Supriyanto \\ Jurusan Kriya \\ Fakultas Seni Rupa dan Desain ISI Surakarta
}

\begin{abstract}
Abstrak
Kriya mempunyai cakupan yang sangat luas salah satunya adalah kriya kayu, dimana konsentrasi penggunaan bahan baku utamanya didominasi bahan baku kayu. Diantara keragaman produk kriya kayu adalah produk kerajian sangkar burung. Dari data yang ada diketahui bahwa dalam 10 tahun terakhir telah mengalami booming. Hal ini karena banyaknya muncul peternak burung sebagai komoditiperdagangan maupun banyaknya komunitas-komunitas pecinta burung baik dari kalangan masyarakat ekonomi lemah hingga masyarakat menengah dan atas. Kebutuhan sangkar burung meningkat dengan pesat hampir merata di setiap daerah dan berdampak pula muncul sentra kerajinan sangkar burung sebagai kantong penghasil sangkar burung. Salah satunya sentra kerajinan sangkar burung dikalurahan Kadipiro, Banjarsari, Surakarta. Terdapat beberapa permasalahan yang menjadikendala di sentra kerajinan sangkar burung di kalurahan Kadipiro Surakarta, diantaranya adalah; Tidak mampu memproduksi dalam waktu yang singkat, tidak adanya standarisasi produk fungsional, kurangnya tenaga kerja trampil dalam mengembangkan produk. Tidak ada produk dengan branded tertentu sehingga mudah ditiru. Berpijak dari permasalahan dan kondisi di sentra kerajinan sangkar burung Kadipiro maka dilakukan kegiatan peningkatan pengembangan produk sangkar burung melalui program PPM, dengan target pengusaha bernama Yudi Haryadi yang saat ini sedang merintis kerajinan sangkar burung bernama "Carisa Sangkar". Fokus dari kegiatan PPM ini lebih diarahkan pada pada aspek peningkatan kualitas produk karya kriya kayu khususnya sangkar burung dengan pembuatan desain yang baik sampai menjadi prototype. Kemudian dilakukan penguatan sumber daya manusia, melalui pendampingan lapangan, yang diharapkan dapat meningkatkan penjualan dan sekaligus secara tidak langsung dapat meningkatan kesejahteraan masyarakat.
\end{abstract}

Kata kunci : Kriya, kreativitas, sangkar burung, sistem produksi 


\begin{abstract}
Craft has a very broad scope one of which is wood craft, where the concentration of the use of raw materials is mainly dominated by wood raw materials. Among the wood craft products are bird cage. It is known that in the last 10 years becoming the peak season. This is due to the large number of bird breeders emerging as trade commodities as well as the many bird-loving communities from among the economically weak to the middle and upper classes. The need for bird cages is rapidly increasing almost evenly in every area and the impact is also emerging centers of bird cage crafts as bird cage producers. One is a bird cage craft center in Kadipiro, Banjarsari, Surakarta. There are a number of problems that have become obstacles in the bird cage handicraft center in Kadipiro Surakarta, including not able to produce in a short time, there is no standardization of functional products, lack of skilled workforce in developing products. There is no specific branded product so it is easy to imitate. Based on the problems and conditions in the Kadipiro bird cage craft, activities to improve the development of bird cage products through the community service, with the target of a businessman named Yudi Haryadi who is currently pioneering a bird cage craft called "Carisa Cage". Improving the quality of wood craft products, especially birdcages by making good designs to become prototypes. Then do strengthening human resources, through field assistance, which is expected to increase sales and at the same time indirectly improve community welfare.
\end{abstract}

Keywords: crafts, creativity, bird cage, production system

\section{PENDAHULUAN}

Karya kriya pada umumnya dibuat dengan menggunakan keterampilan tangan (hand skill) dan memperhatikan segi fungsional (kebutuhan fisik) dan keindahan (kebutuhan emosional). ${ }^{1}$ Karya kriya atau bisa juga disebut dengan produk kriya, dikategorikan sebagai karya seni rupa terapan. Dalam perkembangannya, karya kriya identik dengan seni kerajinan. Salah satu jenis kriya yang menonjol diantaranya adalah kriya kayu, dimana konsentrasi penggunaan bahan baku utamanya didominasi bahan baku kayu. Kriya kayu sangat berkembang pesat di tengah-tengah masyarakat, dengan varian produknya yang sangat beragam, mulai dari mebeler sampai pada produk souvenir kayu. Diantara keragaman produk kriya kayu adalah produk kerajian sangkar burung, dimana dalam 10 tahun terakhir mengalami booming. Hal ini karena banyaknya muncul peternak burung sebagai komoditi perdagangan maupun banyaknya komunitas-komunitas pecinta burung baik dari kalangan masyarakat ekonomi lemah hingga masyarakat menengah dan atas. Hal yang senada juga di sampaikan oleh pesiden RI bapak Joko
Widodo dalam sebuah festival dan pameran burung berkicau tingkat nasional memperebutkan Piala Presiden di Kebun Raya Bogor.

"Presiden Joko Widodo atau Jokowi mengungkapkan, hobi memelihara burung yang ada di Indonesia telah berhasil menggerakkan perekonomian kerakyatan. Angkanya fantastis, mencapai Rp 1,7 triliun per tahun. 'Untuk ekonomi, perputarannya mencapai Rp 1,7 triliun per tahun. Artinya, di sisi penangkaran, pakan, sangkar, obatobatan," kata Presiden Jokowi kepada wartawan di Kebun Raya Bogor, Ahad, 11 Maret 2018"2

Dari sini secara tidak langsung memicu banyak munculnya sentra-sentra atau pusat kerajinan sangkar burung. Salah satunya yang berada di kelurahan Kadipiro kecamatan Banjarsari Surakarta. Kerajinan sangkar burung yang berkembang adalah kerajinan yang dibuat dengan bahan baku bambu dan kayu. Sangkar burung yang diproduksi memiliki ciri khas tersendiri, yaitu jeruji yang halus. 


\section{Abdi Seni Jurnal Pengabdian Kepada Masyarakat}

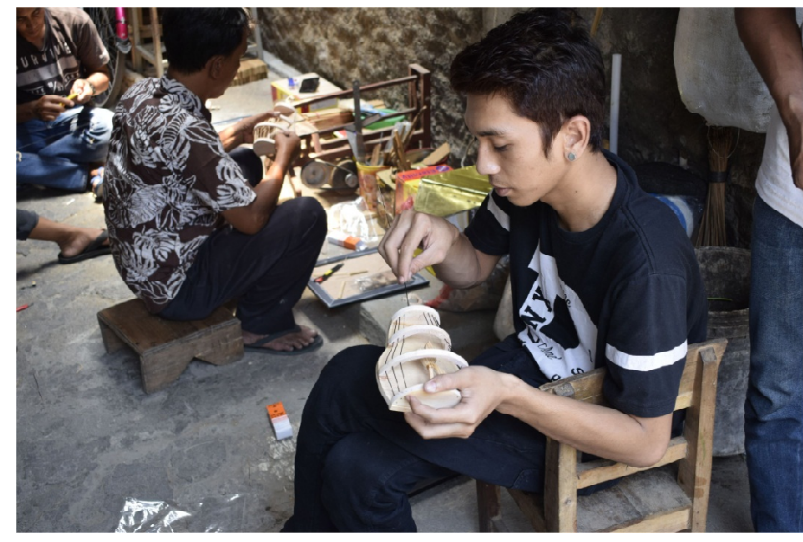

Gambar 1. situasi di sentra kerajinan sangkar burung di kadipiro, sangat menggeliat hidup, namun mayoritas masih manual dan belum banyak dilakukan inovasi pada produknya.

(Foto : R. Adi Prabowo, 2019)

Kelurahan Kadipiro yang memiliki luas wilayah 508,8 Ha ini terbagi dalam 33 Rukun Warga (RW) dan 216 Rukun Tetangga (RT), merupakan daerah perkotaan, sehingga lahan untuk pertanian dan peternakan sangat sedikit. Kelurahan Kadipiro terletak di batas Kota Surakarta sehingga masyarakatnya sebagian besar mempunyai ciri sebagaimana masyarakat perkotaan, Heterogenitas penduduknya cukup tinggi, baik dari segi pendidikan, ekonomi, sosial dan budaya.

Berbagai macam potensi di Kelurahan Kadipiro diantaranya kerajinan limbah kayu, pengrajin sangkar burung, pengrajin celengan dari kaleng bekas serta kampong iklim yang mendapat penghargaan dari Pemerintah Pusat. Kerajinankerajinan yang berada di Kelurahan Kadipiro ini merupakan UKM yang bisa mengangkat pendapatan bagi masyarakat sekitar maupun kota Solo pada umumnya. Seiring dengan berjalannya waktu, kerajinan yang ada di Kelurahan Kadipiro berinovasi sesuai dengan kebutuhan pasar saat ini, tanpa meninggalkan kesan tradisional.

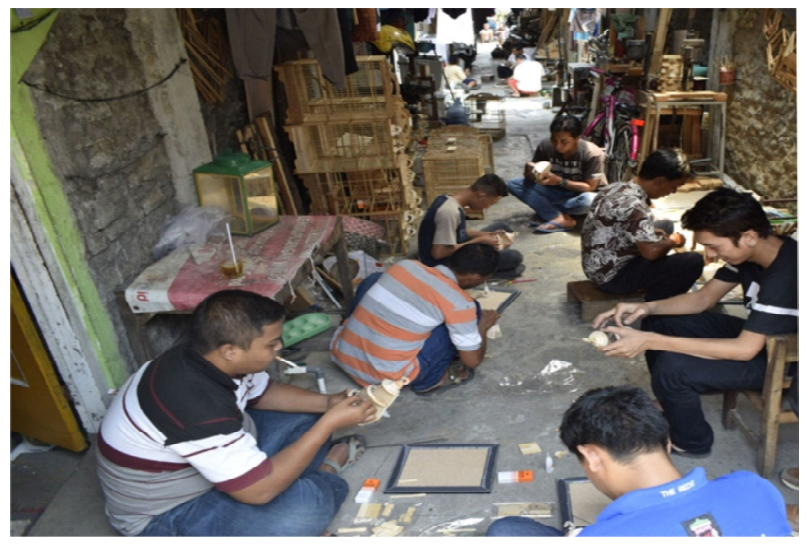

Gambar 2. kegiatan di UKM mitra di sentra kerajinan sangkar burung kadipiro Surakarta.

(Foto : R. Adi Prabowo, 2019)

Sementara ini dari hasil pengamatan terakhir perkembangan kerajinan kayu di Sentra kerajinan sangkar burung kadipiro Surakarta dari aspek deversifikasi produk yang berdampak pada sektor ekonomi bisa dikatakan hanya berjalan di tempat. Padahal sebelumnya mengalami perkembangan yang sangat pesat. Dari hasil observasi, beberapa sebab yang menjadi kendala diantaranya adalah, Kurangnya tenaga kerja trampil dari kalangan pemuda pada lingkungan sekitar kampung, tidak ada produk dengan branded tertentu sehingga mudah ditiru. Berdasar kajian tentang kondisi sentra kerajinan sangkar burung di Kalurahan Kadipiro Surakarta seperti yang telah disampaikan di atas, maka perlu dilakukan PPM untuk UKM, dengan target mitra bernama Yudi Haryadi. Saat ini UKM tersebut sedang merintis kerajinan sangkar burung bernama "Carisa Sangkar" dan berkeinginan untuk mengembangkan usaha produksinya.

Fokus dari PPM ini lebih diarahkan pada pada aspek peningkatan kualitas produksi yang meliputi penguatan sistem produksi, penguatan sumber daya manusia, perancangan desain, dan branding produk yang akhirnya bermuara pada peningkatan kualitas produk dan perluasan pasar. Mitra tersebut dapat dikatakan sudah memiliki skill dasar, namun dalam hal aplikasi teknologi dan efisiensi masih membutuhkan pelatihan dan 
pendampingan. Demikian halnya dengan upaya untuk menciptakan desain dan

pembuatan pengembangan produk, dapat dikatakan belum mampu sehingga masih sangat membutuhkan hasil kajian ilmiah dari akademisi perguruan tinggi. Atas dasar realitas tentang potensi dan peluang usaha, aspek produksi dan manajemen usaha, serta eksistensi sumber daya yang dimiliki pengusaha kerajinan sangkar burung tersebut maka nampak jelas begitu perlunya dilakukan PPM peningkatan produk karya kriya kayu di Sentra Kerajinan Sangkar Burung kadipiro Banjarsari Surakarta.

\section{METODE}

Metode pelaksanaan kegiatan yang dipilih akan sangat menentukan tingkat keberhasilan suatu kegiatan. Adapun beberapa metode yang digunakan pada kegiatan ini meliputi hal-hal sebagai berikut:

1. Metode ceramah plus.

Merupakan metode yang bertujuan memberikan pengetahuan dan petunjukpetunjuk dimana terdapat audien yang bertindah sebagai pendengar. Ceramah, dapat dilakukan dengan cara kreatif dan inovatif ${ }^{3}$. Metode ceramah plus adalah metode mengajar yang menggunakan lebih dari satu metode, yakni metode ceramah yang digabung dengan metode lainnya. Pada kegiatan ini perpaduan metode yang digunakan adalah metode ceramah plus demonstrasi dan latihan

2. Metode bimbingan dan pendampingan.

Pendampingan adalah pekerjaan yang dilakukan oleh fasilitator atau pendamping dalam kegiatan program IbPE. Fasilitator tugasnya lebih sebagai pendorong, penggerak, katalisator, motivator, pengarah dan pembimbing ${ }^{4}$ Pasca kegiatan pelatihan kegiatan selanjutnya adalah praktek produksi produk kerajinan. Pendampingan menjadi sangat penting untuk membimbing dan menjaga kualitas produk yang dihasilkan.
3. Desain dan Aplikasinya.

Metode ini untuk memberi beberapa alternatif desain baru bagi UKM mitra yang berbasis pada tren pasar mengacu nilai-nilai budaya yang berkembang pada masyarakat.

\section{PEMBAHASAN}

Pelaksanaan PPM dilakukan dengan kegiatan pendampingan dan kegiatan pelatihan. Pendampingan atau fasilitator merupakan kegiatan dalammemahami peran-peran yang dijalankan di masyarakat khususnya para pengrajin sangkar burung serta memiliki keterampilan teknis menjalankannya, yakni keterampilan memfasilitasi proses-proses yang membantu, memperlancar, agar mampu melakukan sendiri semua peran yang dijalankan oleh pendamping. Salah satu fungsi paling pokok dari pendampingan adalah memfasilitasi komunitas atau masyarakat yang didampinginya. Memfasilitasi dalam artian tidak hanya memfasilitasi proses- proses pelatihan atau pertemuan saja, melainkan memahami peran-peran yang dijalankan serta memiliki keterampilan teknis menjalankannya.

Pendekatan menggunakan pendekatan persuasif. Pendekatan ini dilakukan berlandaskan asumsi bahwa para pengrajin sangkar burung tahu apa yang sebenarnya mereka butuhkan dan tentunya menjadi lebih baik. Pada pendekatan ini, pemeran utama dalam suatu perubahan adalah pengrajin sangkar burung itu sendiri. Dalam tahap ini pengrajin diberikan kesempatan untuk membuat dan mengambil keputusan yang berguna bagi mereka sendiriuntuk mencapai tujuan yang mereka inginkan, namun tidak menyalahi peraturan yang ada. Tujuan dalam pendekatan ini adalah agar pengrajin sangkar burung memperoleh pengalaman belajar untuk mengembangkan dirinya melalui pemikiran dan tindakan yang dirumuskan oleh mereka. Pendekatan ini sering disebut pendekatan yang bersifat persuasif. ${ }^{5}$ 
Beberapa langkah-langkah dalam strategi pendampingan yang dilakukan PPM ini yaitu:

\section{Menganalisis keadaan}

Menganalisis bertujuan untuk memperoleh pemahaman yang jelas mengenai perkembangan keadaan yang sedang berjalan beserta seluruh latar belakang permasalahannya. Analisis ini harus dilakukan bersama kelompok atau komunitas dalam hal ini adalah pengrajin sangkar burung yang merasakan dampak perkembangannya. Setelah analisis keadaan dilanjutkan analissis dengan terjun langsung ke lapangan. Kesempatan ini adalah proses menganalisis untuk mengetahui situasi keadaan yang terjadi di lapangan sentra kerajinan sangkar burung. Perlu diketahui oleh pendamping adalah mengenai keadaan dan potensi- potensi yang ada.

\section{Menyamakan persepsi}

Pendampingan dimulai dari masalah yang ada di pengrajin sangkar burung. Pendamping melakukan persamaan persepsi dari masalahmasalah yang dihadapi oleh pengrajin. Pada proses ini perlu diadakannya diskusi dan membangun gagasan bersama. Forum diskusi yang dilakukan bukanlah forum resmi. Dengan pendekatan melalui cerita-cerita umum maupun pribadi kemudian berlanjut pada permasalahan yang ada.

\section{Menilai kekuatan dan kelemahan}

Pada tahap ini yaitu sebuah proses di mana pendamping mengajak objek PMM dalam hal ini para pengrajin sangkar burung untuk menganalisis kekuatan dan kelemahan mereka sendiri. Bagaimana caranya memperkecil kelemahan pada saat bersamaan semakin memperbesar kemampuan dan kekuatan yang mereka miliki, sampai sejauh mana kelemahan tersebut dapat menghalangi usaha pencapaian tujuan, dan bagaimana mencegah serta kemungkinan apa yang harus dilakukan jika hal itu terjadi. Pada bagian ini pendampingan akan memasuki proses menuju perubahan. Kemudian mempersiapkan proses membangun sebuah kelompok. Selanjutnya setelah beberapa kelompok pengrajin mengetahui dan sadar akan situasi dan kondisi diri, maka pendamping bersama pengrajin memberikan penilaian terhadap kekuatankekuatan dan potensi yang ada pada pengrajin sangkar burung.

\section{Mengerahkan tindakan menata kebersamaan}

Kegiatan ini sebagai bentuk kegiatan sederhana yang melibatkan kelompok kecil yang dilakukan dengan sengaja untuk tujuan bersama. Pengerahan aksi bersama bukan hanya sekedar untuk membangkitkan kembali semangat para pengrajin yang lemah, melainkan juga berhasil menumbuhkan kembali rasa percaya diri mereka untuk mulai kembali berupaya mengatasi masalah dan mengubah keadaan tentunya mengarah yang lebih baik.

\section{Kegiatan Pendampingan}

Pendampingan yang dilakukan pada kegiatan PPM ini antara lain sebagai berikut :

\section{Pendampingan pembuatan logo dan media promosi}

Pembuatan logo diperlukan dalam rangka mengenalkan identitas sebagai bentuk branding produk sangkar burung. Logo juga diperlukan dalam pembuatan media promosi seperti untuk pembuatan katalok produk, pembuatan media on line. Logo juga diperlukan untuk menandai produk yang telah dihasilkan. Selain itu juga digunakan pada identitas usaha sangkar burung.

\section{Pendampingan penataan tata letak produksi}

Penataan tata letak produksi sangat diperlukan oleh pengrajin sangkar burung (bapak Yudi Haryadi). Hal ini dilakukan agar kualitas produksi dan kecepatan produksi yang ada di UKM pengrajin sangkar burung dapat lebih baik lagi. 


\section{Pendampingan pengembangan desain model baru}

Pendampingan pengembangan desain model baru diperlukan agar muncul variasi produk sangkar burung yang dihasilkan. Pengembangan model baru berupa beberapa penambahan ornamen pada sangkar burung. Teknik penambangan ornamen dengan cara memberikan ornamen sungging, teknik ukir, teknik cukit dan finising cat.

Berikut contoh produk melaui pengembangan ornamen teknik sungging yang dilakukan pada salah satu pengrajin sangkar burung di kadipiro Surakarta sebagai berikut.

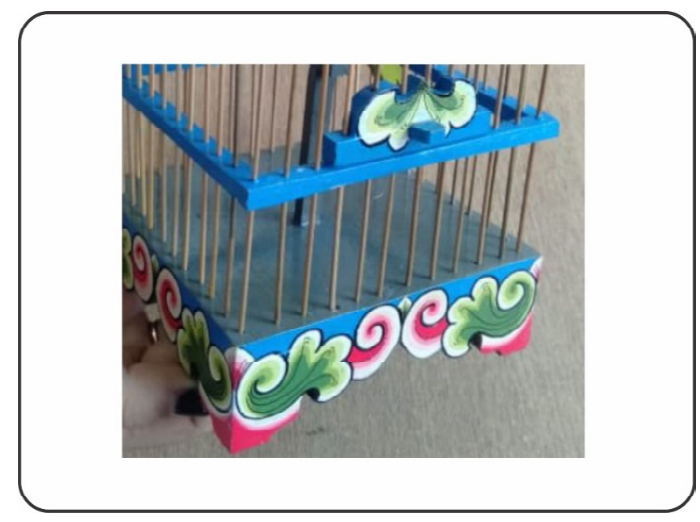

Gambar 3. Teknik Sungging pengembangan desain model baru pada sangkar burung yang dilakukan di pengrajin sangkar burung Kadipiro Surakarta

\section{Pendampingan pengembangan produk turunan}

Pengembangan produk turunan yang dimaksud disini adalah produk kerajinan yang berwujud souvenir. Pengembangan ini penting agar stabilitas usaha UKM dapat terus berkembang. Hal tersebut karena produk sangkar burung yang selama ini dipasarkan terkadang terdapat masamasa jeda dimana pada masa tersebut penjualan sangkar burung mengalami penurunan. Masa jeda tersebut biasanya di bulan Juli Agustus di mana pada bulan tersebut merupakan masa tahun ajaran baru masuk sekolah. Selain itu masa jeda juga terjadi pada sat bulan puasa sampai idul fitri.
Berpijak dari hal tersebut maka dengan pengembangan produk turunan yang berupa souvenir setidaknya dapat menjadi alternatif produk selain sangkar burung sehingga pada masa jeda tetap ada produksi.

\section{Kegiatan Pelatihan Pembuatan Souvenir}

Pelatihan dilakukan dengan tujuan untuk menambah wawasan dan pengetahuan para pengrajin sangkar burung. Pelatihan dilakukan dengan mengambil sub tema sovenir pengembangan sangkar burung, dimaksudkan agar para pengrajin sangkar burung mampu mengembangankan produknya, tidak berhenti pada sangkar burung saja tetapi juga mampu mengembangkan produk turunannya. Diharapkan dengan pelatihan ini para

pengrajin sangkar burung mampu memunculkan produk-produk baru berupa souvenir yang mengacu pada model maupun desain yang sudah dimiliki para pengrajin yaitu sangkar burung.

Alternatif souvenir yang dibuat dalam pelatihan tersebut antara lain :

1. Souvenir sangkar burung mini

2. Souvenir gantungan kunci

3. Souvenir hiasan interior

4. Souvenir lampu gantung

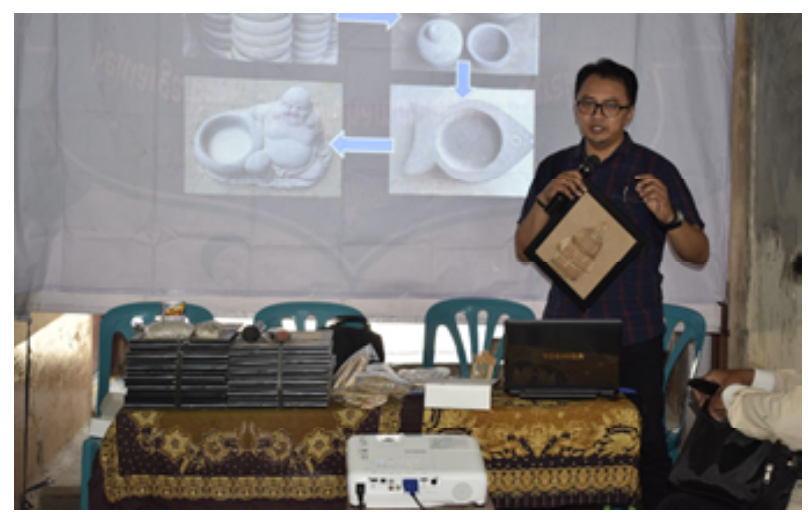

Gambar 4. narasumber pelatihan memberi materi pengembangan produk sovenir yang menjanjikan pasar.

(Foto : R. Adi Prabowo, 2019) 


\section{Abdi Seni Jurnal Pengabdian Kepada Masyarakat}

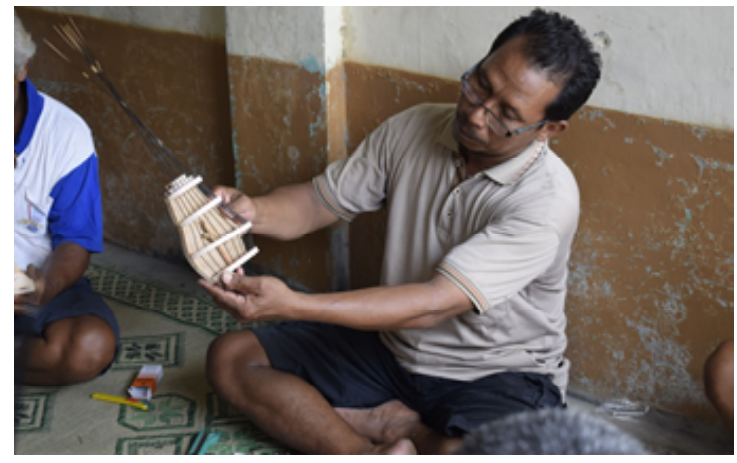

Gambar 5. Salah satu rancangan sovenir karya peserta pelatihan.

(Foto : R. Adi Prabowo, 2019)

\section{Karya Seni Hasil PPM}

Karya seni yang menjadi proto tipe dan menjadi salah satu dari beberapa sample produk pengembangan sangkar burung adalah sovenir sangkar mini. Karya ini merupakan produk sovenir yang berfungsi sebagai penghias ruang atau menjadi elemen interior. Berikut salah satu hasail PPM yang merupakan karya seni yang digunakan sebagai acuan oleh para pengrajin untuk menghasilkan produk turunan sangkar burung.

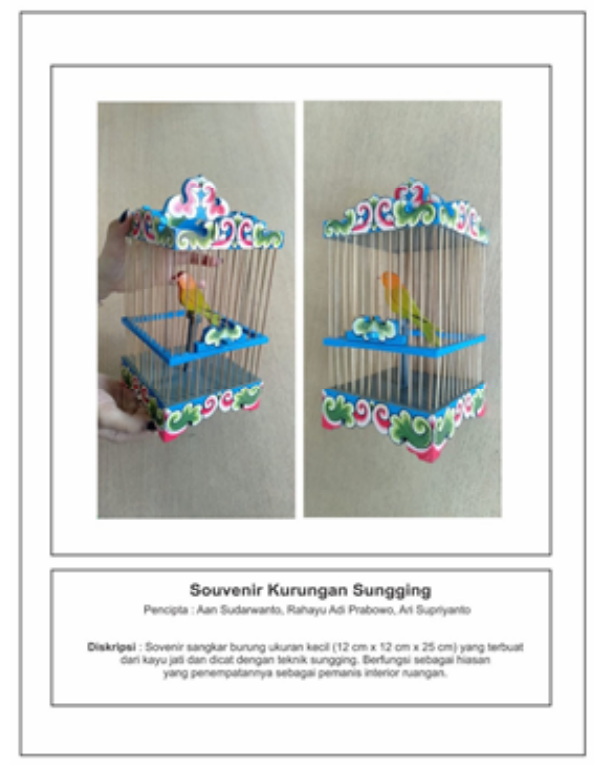

Gambar 6. Salah satu karya seni hasil PPM berupa souvenir kurungan sungging yang digunakan sebagai salah satu acuan pengembangan produk sangkar burung.

\section{KESIMPULAN}

Berpijak pada pengamatan di sentra kerajinan sangkar burung kadipiro Surakarta dari aspek perkembangan produk bisa dikatakan kurang berjalan maksimal. Beberapa sebab yang menjadi kendalanya adalah kurangnya tenaga kerja trampil yang dapat mengembangkan desain produk dan tidak ada produk dengan branded tertentu

sehingga mudah ditiru. Beberapa pendekatan yang telah dilakukan dalam mengurai permasalahan tersebut telah dilakukan melalui pendampingan dan pelatihan. Pendampingan yang dilakukan diantaranya pembuatan logo, diperlukan dalam rangka mengenalkan identitas sebagai bentuk branding produk sangkar burung. Logo juga diperlukan dalam pembuatan media promosi seperti untuk pembuatan katalok produk dan pembuatan media on line.

Pendampingan lain yang dilakukan adalah pengembangan desain model baru. Hal ini diperlukan agar muncul variasi produk sangkar burung yang dihasilkan. Pengembangan model baru berupa memberi beberapa penambahan ornamen pada sangkar burung. Teknik penambangan ornamen dengan cara memberikan ornamen sungging, teknik ukir, teknik cukit, dan finishing cat.

Selain dilakukan pendampingan juga dilakukan pelatihan. Pelatihan dilakukan dengan tujuan untuk menambah wawasan dan pengetahuan para pengrajin sangkar burung. Pelatihan dilakukan dengan mengambil tema souvenir pengembangan sangkar burung, dimaksudkan agar para pengrajin sangkar burung mampu mengembangankan produknya, menjawab kendala yang selama ini terjadi.

\section{Catatan Akhir:}

${ }^{1}$ Soegeng Toekio, at all, 1987, Pengantar Apresiasi Seni Rupa, ASKI Surakarta, p. 12

${ }^{2}$ TEMPO.CO Reporter: Antara Editor: Rr. Ariyani Yakti Widyastuti Senin, 12 Maret 2018 
09:31 WIB. Link https://bisnis.tempo.co/read/ 1068829/jokowi-sebut-perputaran-uang-di-bisnishobi-burung-capai-rp-17-t/full\&view $=$ ok

${ }^{3}$ Soedarsono RM, Metodologi Penelitian Seni Pertubjukan dan Seni Rupa, (Bandung : MSPI, 2001) p.57

${ }^{4}$ Ambar Teguh Sulistiyani, Kemitraan Dan Model Model Pemberdayaan, (yogyakarta : Gava Media, 2004), p. 76

${ }^{5}$ Isbandi Rukminto Adi. Intervensi Komunitas dan Pengembang Masyarakat (sebagai upaya pemberdayaan masyarakat).Jakarta: PT. Raja Grafindo Persada, 2012. Hal 167-168.

\section{DAFTAR PUSTAKA}

Agus Sachari, 2002, Estetika, Makna Simbol dan Daya, Bandung : Penerbit ITB
Agus Sachari, Yan Yan Sunarya, 2002, Sejarah dan Perkembangan Desain dan Dunia Kesenirupaan di Indonesia, Bandung : Penerbit ITB

Ambar Teguh Sulistiyani, 2004, Kemitraan Dan Model Model Pemberdayaan, yogyakarta : Gava Media

Soegeng Toekio, at all, 1987, Pengantar Apresiasi Seni Rupa, ASKI Surakarta

Soedarsono RM, 2001, Metodologi Penelitian Seni Pertubjukan dan Seni Rupa, Bandung: MSPI

Isbandi Rukminto Adi. 2012., Intervensi Komunitas dan Pengembang Masyarakat (sebagai upaya pemberdayaan masyarakat).Jakarta : PT. Raja Grafindo Persada. 